Article

\title{
Losing Touch: A Theology of Death for Michael Haneke's Amour
}

\author{
Taylor Worley
}

Department of Philosophy, Trinity International University, 2065 Half Day Road, Village of Bannockburn, Deerfield, IL 60015, USA; tbworley@tiu.edu; Tel.: +1-847-317-4061

Academic Editor: Joseph Kickasola

Received: 26 July 2016; Accepted: 16 November 2016; Published: 30 November 2016

\begin{abstract}
This proposed theology of death for Michael Haneke's Amour, a fraught but poignant piece of cinema, will employ Martin Heidegger's existentialism to reframe the ethical structure of the film and apply a "lived theology" rejoinder to its perceived hopelessness. The proposal will address the question of ethics in relation to Haneke's cinema, in particular his seemingly nihilistic perspective and confrontational style. To do so, it will revisit the film itself and examine the ways that Georges and Anne's love is tested. Principally, we examine the film's great question, which-in the filmmaker's own words-is: "How do I cope with the suffering of a loved one?" With aid from the theologian Dietrich Bonhoeffer, this 'lived theology' proposal will attempt to give an account of love's irrepressible strength in the midst of even astounding suffering. While Heidegger's ethic of resoluteness calls for interiority and solitude, Bonhoeffer's account of death more satisfactorily invokes a transcendent summons contained within our own pledges to loved ones. Such a theological reading of Haneke's Amour will draw two distinct conclusions: first, the film exposes the superficiality of any hoped-for solitude or escape from a loved one's death, and secondly, it demonstrates that the mutuality of authentic love entails impossible sacrifices.
\end{abstract}

Keywords: Michael Haneke; Martin Heidegger; Dietrich Bonhoeffer; cinema; death; love; existentialism

"To find dignity in suffering is only possible through love and compassion. That is most difficult. As love is a difficult thing. It is not given to everyone."

-Michael Haneke ${ }^{1}$

\section{Introduction}

In Amour, audiences encounter Georges and Anne, an octogenarian couple living out their golden years in relative ease and tranquility. There is nothing particularly noteworthy about this pair of retired music teachers. They operate like many elderly spouses, cherishing and tolerating one another in almost equal parts ${ }^{2}$. Their peaceful lives are abruptly redirected by the sudden onslaught of Anne's stroke, dementia, and terminal decline. Quiet moments of disappointment, pain, and bitterness multiply and expand as the film continues. Rather than lessening the effect of the loss, Haneke allows it to be subtly amplified through each successive stage of Anne's deterioration and Georges's growing

1 The highly acclaimed auteur filmmaker Michael Haneke shared these words as part of an interview conducted in Yves Montmayeur's 2013 documentary Michael H. Profession: Director. Following the recent release of Haneke's Amour (2012), the documentary demonstrates the unique appeal of Haneke's cinematic vision given the reputation his films have for disturbing audiences and courting associations with absurdist existentialism and nihilism [1].

2 Richard Brody rightly notes that there is nothing particularly special about this couple: "Georges is a musicologist, it seems; Anne is a piano teacher; they're a long-married couple, they're retired; they listen to music, read, attend concerts, are in tenuous touch with their grown daughter, also a classical musician. Not a hair or an opinion is out of place-the characters just rumpled and informal enough not to seem stuffy." [2]. 
despair. As Roy Grundmann relates, "It is this test of their love-and even more, the radical mutation their love undergoes when put to this test-on which Amour pivots." ${ }^{3}$ We come to feel, in concert with the characters, a profound sense of their misery and desperation. We experience the unbearable tension that pushes their love for one another to impossible limits and ultimately forces an unlikely "mutation" with drastic consequences. Haneke's Amour provokes us to see in new and unavoidable ways that, simply put, love can ruin us (see Figure 1).

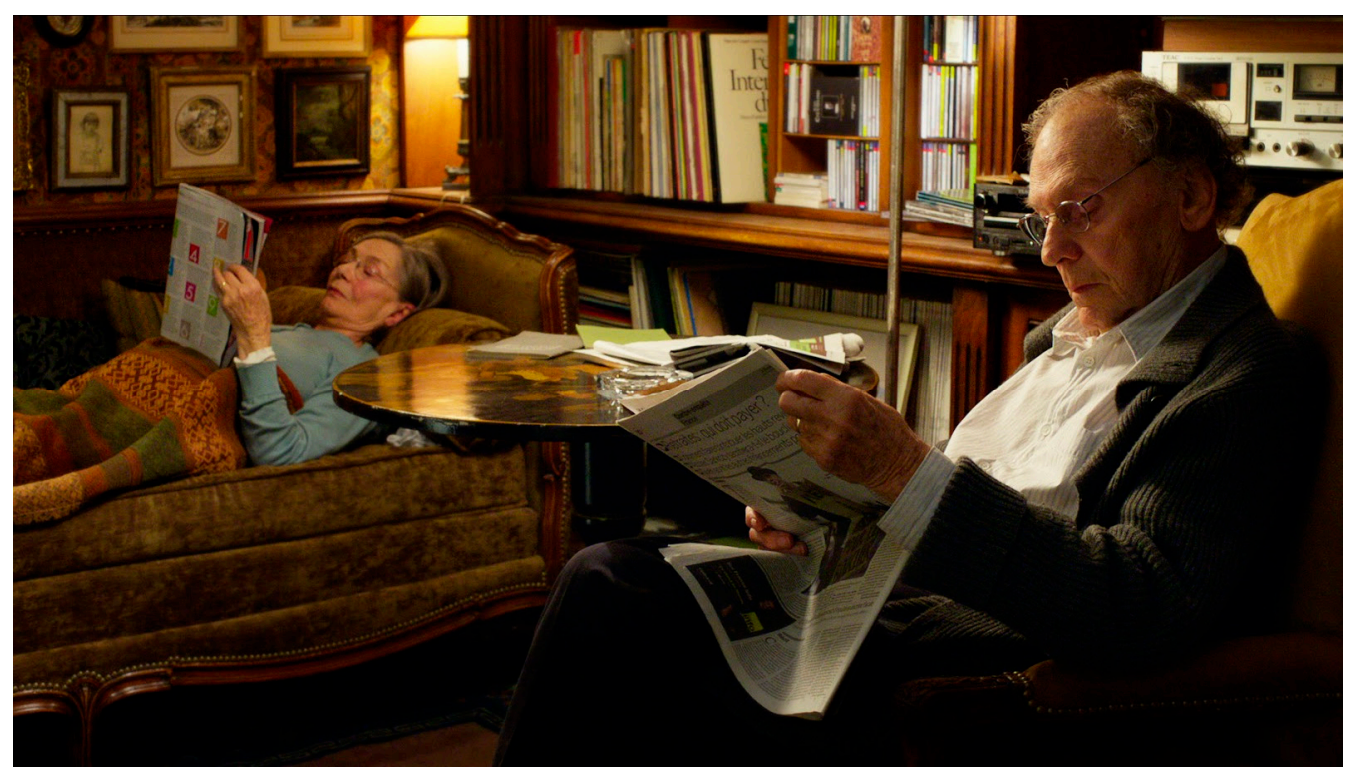

Figure 1. Georges and Anne's simple life together.

Amour was met by bewilderment, outrage, and disgust in some critics-much of it focused on the startling climax of the film ${ }^{4}$. The film ends with Georges's unexpected and horrifying decision to end his wife's suffering, which by consequence, leads to his own mental and emotional collapse in the wake of what he has done. While some reviewers cannot untangle Amour's account of love in the face of death from the inclusion of its startling mercy killing, Haneke himself attempted to clarify his intentions in an interview, saying:

First of all, it's the case that with old people, especially when they're sick, the world shrinks to the four walls they live within. They shut out the world: it's a challenge they can't cope with. Also, I wanted to avoid making my film a 'social drama.' There have been enough films that present these themes as a social drama, that deal with context and environment, with hospitals, ambulances and doctors. That's not what I was trying to do. I didn't want to make a social drama, but an existential drama that deals with the question: 'How do I cope with the suffering of a loved one?' [6].

3 Grundmann, for example, sees in Amour all the characteristic intensity that Haneke typically focuses into the violence and terror of his other films: "Yet Haneke's portrayal of their mellow love that, somewhat surprisingly, is just as sustained and detailed as his previous studies of violence and dysfunction, is put to the test by an illness that Anne suffers not long into the film and that leaves her gradually but ineluctably incapacitated. It is this test of their love — and even more, the radical mutation their love undergoes when put to this test-on which Amour pivots." [3]. Cf. [4].

4 Writing for The New Yorker, Richard Brody described the film as "sterile," and ultimately of Haneke's attempts at empathy, he found them unsuccessful and actually "repellant." Brody, "Michael Haneke's Sterile Amour." Consider also the conflicted account in [5]. Prose claims that, "Amour is the ultimate horror film ... it's far scarier and more disturbing than Hitchcock's Pyscho, Kubrick's The Shining, or Polanski's Rosemary's Baby, and like those films, it stays with you long after you might have chosen to forget it." 
According to Haneke, Amour is thoroughly concerned with the dilemma of death, but if we attempt to understand its treatment of death from the perspective of a social ethic or a test case for application in our lives, we have lost all its weight. Rather, we must consider this film less a moral fable and more a philosophical meditation on death. Even if we are preoccupied with determining whether or not Georges's horrific act constitutes murder, the philosophical orientation of the film does not privilege this concern above all others. The presence of euthanasia in the film is meant to test the limits of the audience's empathy and drive home its ethical self-reflexivity, a concept to be explored more fully below. Haneke is not interested in a "social drama" but something more existential—something that embodies his brief words about dignity in the midst of suffering: "To find dignity in suffering is only possible through love and compassion. That is most difficult. As love is a difficult thing. It is not given to everyone."

If Amour should not be read for a social ethic, how then should we understand its philosophical orientation? Quite simply, Amour invites us to recover an authentic experience with the thought of death, a topic over which the figure of Martin Heidegger looms large (Cf. [7] or [8]). In a fashion truly reminiscent of Heidegger's appeal to authenticity in the face of death, Haneke forces his audience to face death in newly constrained and concentrated ways. Amour raises questions for us that we would rather not consider, but having experienced it, we cannot avoid its effects. We must seek to answer the question that Haneke's Amour poses: "How do I cope with the suffering of a loved one?"

While Heidegger helps us recover a means of "thinking death" in Haneke's Amour, the test of love that it presents begs ultimate questions that are theological in nature. Theology, here, refers particularly to ultimate beliefs as they are lived out. "Lived Theology," as Todd Dubose defines it, "is the enactment of that, which is most significant to us at any given moment and as lived out in our everyday existence, rather than the systemization of creedal propositions of any given faith tradition" [9]. Therefore, while Heidegger's existentialism provides a philosophical frame for engaging with Haneke's film, we turn to a "lived theology" strategy for answers. As will become evident below, Heidegger's response to the death of another is basically incomplete. His recourse to resoluteness and solitude cannot account for the lengths that love will go to in fulfilling its obligations. Heidegger's response invites indifference-the opposite of love. Instead, the forceful picture in Amour of the shattering demands of love points to a transcendent reality beyond what even death can touch. In his critique of Heidegger, the modern theologian Dietrich Bonhoeffer grounds the risk of love in the powerful summons of divine address we meet in the demands of loving another person. What Heidegger calls simply conscience, Bonhoeffer understands to be the transcendent call of God. Faced with the suffering and eventual death of a loved one, this call should not be avoided or silenced—as in Heidegger's ethic of resoluteness-but instead maintained and heeded, even to the point of unimaginable sacrifice. Amour does not function without this sustained denial of indifference. Despite its horrific outcome, the film demonstrates Georges's inability to ultimately escape from the divine address that confronts him in the ethical demand to love his wife to the end.

This proposal of a theology of death for Haneke's Amour will demonstrate an informed but still novel take on the film and proceed in the following ways. First, we will address the question of ethics in relation to Haneke's cinema, in particular his seemingly nihilistic perspective and confrontational style. Next, we will establish the Heideggerian frame of this proposal by returning to Being and Time's discourse on death and the accompanying value placed on anxiety, resoluteness, and solitude. Then, we will revisit the film itself and examine the ways that Georges and Anne's love is tested. Finally, we will offer a theological response to the ethical ambiguity of Haneke's Amour and draw some conclusions along two distinct lines. Initially, we will consider the ways in which Haneke's film exposes the superficiality of Heidegger's account of resoluteness, and then, we will develop a positive account of what a theological engagement with Amour might substitute for resoluteness. Let us now proceed to the question of ethics in Haneke's cinema. 


\section{Reassessing the Ethics of Haneke's Cinema}

Known for a string of unsettling films, such as Funny Games (1997 original, 2007 English language remake), Caché (2005), and The White Ribbon (2009), this offering is surely one of Haneke's most humane portraits ${ }^{5}$. With remarkable restraint, he attends to the gradual erosion of Georges and Anne's relationship and their subsequent descent into despair and isolation. Both the pace of the storytelling and the choice to restrict it almost exclusively to events taking place in the couple's Parisian apartment make this film Haneke's most unassuming venture to date. Indeed, this film belongs alongside the rest of his work in that it shares the same unapologetically philosophical posture. His films stand in stark opposition to the totalizing and uncritical perspective represented by Hollywood or, what he calls, "the cinema of distraction." ([10], p. 139). In an effort to avoid the falsity of what passes for cinema today, Haneke acknowledges the inescapably manipulative nature of film and tries to foreground our complicit participation in the lie of the screen ${ }^{6}$ He explains that, "The question is not: 'What am I allowed to show?' but rather: 'What chance do I give the viewer to recognize what it is I am showing?"' ([11], p. 579). As McCann and Sorfa emphasize, "Haneke's films are not ironic," and Amour is no exception to that pattern ([12], p. 3). In the face of an uncritical tabloid culture saturated by fear and media violence, he re-assigns death its proper weight, namely through the loss of the other's touch. But his distinctive commitment to eradicating sentimentality and melodrama from his films makes the emotional minimalism of this tragic story oppressive and exacting for its audience.

While humane and tender in its own way, Amour can be, as one critic put it, "excruciating to watch." With some ambivalence, she concludes: "Michael Haneke is to be praised and admired for filming—so beautifully and so truthfully—straight down into the abyss, and for inviting us to take a long hard look at what's there." [5]. It seems that even in the case of a film about love Haneke's terse and unrelenting style leave audiences initially uncertain of what the film means. Haneke seeks to create such doubt, and he reveals his intentions this way: "My films are intended as polemical statements against the American 'barrel down' cinema and its dis-empowerment of the spectator. They are an appeal for a cinema of insistent questions instead of false (because too quick) answers, for clarifying distance in place of violating closeness, for provocation and dialogue instead of consumption and consensus." (Quoted in [13]). The viewer, then, is greatly provoked and disturbed by what Haneke intends for his audience to experience in his films. Acknowledging this intention on the part of the director is one thing, but making something productive of his cinema is quite another. While many critics celebrate Haneke's achievements, few invest in sustained consideration of the moral value of his aggressive tactics. Fortunately, help is on offer from a small collection of scholars that seek to rehabilitate Haneke's shocking cinema in generative directions, namely the ethical orientation of his films and the moral mechanics they employ.

Kevin Stoehr elaborates on the anti-nihilist character of Haneke's cinema and explains that, "It would be overly easy, from an overly quick survey of Michael Haneke's films, to classify him as an outright nihilist because of his choices of subject matter, not to mention his willingness to undermine audience trust and the traditional logic of narrative truth-telling." ([14]. Cf. [15]). Stoehr, however, identifies a deeply anti-nihilist impulse in Haneke's films: "His films reveal the problem of nihilism in modern society and seek to point beyond the problem. He makes us acknowledge the ugly truth of reality and the consequences of our own eventual numbness, detachment, and indifference."

5 Peter Brunette sees a strong thread of humanist concern running through the whole of Haneke's oeuvre. He quotes Haneke on this very point: "I try in all my films to be a 'humanist' because I think if one is seriously interested in art, you can't do it any other way. Humanism is the sine qua non. Art cannot exist without humanism; it would be a contradiction. It's the most important reason for working. Communication is also a humanistic act. Refusing to communicate is a terrorist act that provokes violence." And Brunette concludes: "Thus, all of Haneke's themes and obsessions-humanity, communication (and its lack), art, violence-come together in one simple equation." ([10], p. 107).

6 Haneke himself explains: "With no matter what film, you're being manipulated, but people are dishonest enough to never say it. I, on the other hand, show it to say it. I think it's the exact opposite position. You can't escape this problematic: as soon as you make a frame, it's already a manipulation. I just try to do it in a transparent manner." ([10], p. 152). 
Stoehr roots his argument for the anti-nihilist character of their films in his own reflection on Friedrich Nietzsche's portrayal of nihilism: "A nihilist is a man who judges of the world as it is that it ought not to be, and of the world as it ought to be that it does not exist. According to this view, our existence (action, suffering, willing, feeling) has no meaning: the pathos of "in vain' is the nihilists" pathos—at the same time, as pathos, an inconsistency on the part of the nihilists." (Quoted in [14]). This ambiguity and indecision at the heart of nihilism produces, for Nietzsche, the binary division of its expression: one negative and deflating - destructive for the individual; the other positive, generative, and affirming to the individual. Stoehr then cites Haneke himself on this point:

I think it can hardly be denied that each fictional story, no matter how abysmal or horrible, is a trifle compared with the horror that strikes against us in reality. In order to see this, one must not be a pessimist-it suffices if one is somewhat awake ... What is positive can only be the merciless demand for personal truthfulness. Only: The truth is no longer beautiful. As Nietzsche already said in the past century: 'For a philosopher it is wretched to say that the good and the beautiful are the same. And if he goes on to add, "and also the Truth!" one ought to clobber him.' The truth is ugly. (Quoted in [14]).

Haneke's interest in protecting the truth qualifies him as something more than a simple nihilist. In relying on Nietzsche here, the filmmaker is acknowledging what the philosopher strained to show: vehemently rejecting society's attempts to beautify the harshness of reality (i.e., conflating goodness, beauty, and truth in Nietzsche's example above) is not the same as vehemently rejecting the truth of reality. Like Nietzsche, Haneke is haunted by the elusiveness of truth and still refuses cheap substitutes for it. Protecting a place for truth—no matter how elusive—is what Stoehr helpfully characterizes in his commentary on both as "positive nihilism." In contrast to a "negative nihilism" that admits the terror of reality and is resigned to it, "positive nihilism" is willing instead to move toward moral and spiritual crisis.

Applying this doubled movement to Haneke's cinema affects a drastic reframing of how we might read his films. We should no longer accept the banal surface of his films as all there is. Remaining with the surface would only lead to a shortsighted and essentially nihilist reading of Haneke. Instead, we should regularly expect there to be much more going on beneath. "There is nevertheless a dark strain of optimism," according to Ben McCann and David Sorfa, "that runs throughout Haneke's work and elevates it above fashionable nihilism." ([12], p. 1). We should see Haneke's sparse and minimalist presentations as clearing some space for a second movement-the impulse of the human spirit to defy what it sees. Such an awakening of our moral and spiritual reflexes is what Catherine Wheatley has in view with her study of the ethical mechanics of Haneke's work.

In Michael Haneke's Cinema: The Ethic of the Image, Wheatley engages the same dilemma that many others experience: "Why, upon watching Haneke's films, do we so often feel irritated, cross, even guilty?" ([16], p. 5). This question led her to explore the ethics of spectatorship at work in Haneke's films, and she discovered that the unsettling nature of his cinema stems from its dynamic of ethical reflexivity in the audiences' experience. Her explorations of Haneke's films then evaluate the link between the aesthetic reflexivity in the formal aspects of his cinema and the moral reflexivity experienced by his audience. Wheatley explains: "By placing reflexive techniques within new frameworks, I argue, Haneke is able to co-opt the spectator into a uniquely moral relationship to the film. Reflexivity in his films is used ... to encourage a more open-ended reflection on the spectator's part about moral questions. On the implicit level, the films prompt their spectators to ask: How are we complicit with the apparatus? What are the moral consequences of this?" ([16], p. 5). In this way, Wheatley dubs Haneke "The Last Moralist," and by this designation, she means that his decisive style prevents audiences from finding ethical resolution solely at the hands of the director. Instead, Haneke forces audiences to take responsibility for their own spectatorship and in his own fashion has prompted the evolution of filmmaking toward a new form of ethical cinema. One commentator describes the value of Wheatley's project thus: "[W]e realize that Haneke's oeuvre no longer reminds us of the satirical violence of Oliver Stone's Natural Born Killers (1994) or Quentin Tarantino's lack of morality in 
Inglourious Basterds (2009), but opens up a truly innovative strategy of looking at film as a philosophical tool that seems to dissect the audience's attitude towards its morals layer by layer." [17]. Consider for example the way in which spectatorship is acknowledged by the extended frame of the audience that Georges and Anne join for the concert in Figure 2. Here the spectatorship of the viewer is mirrored in the gaze of the concert audience starring back. From Wheatley's assessment, this intervention in the formulaic ethics of Hollywood remains Haneke's greatest moral contribution to cinema today.

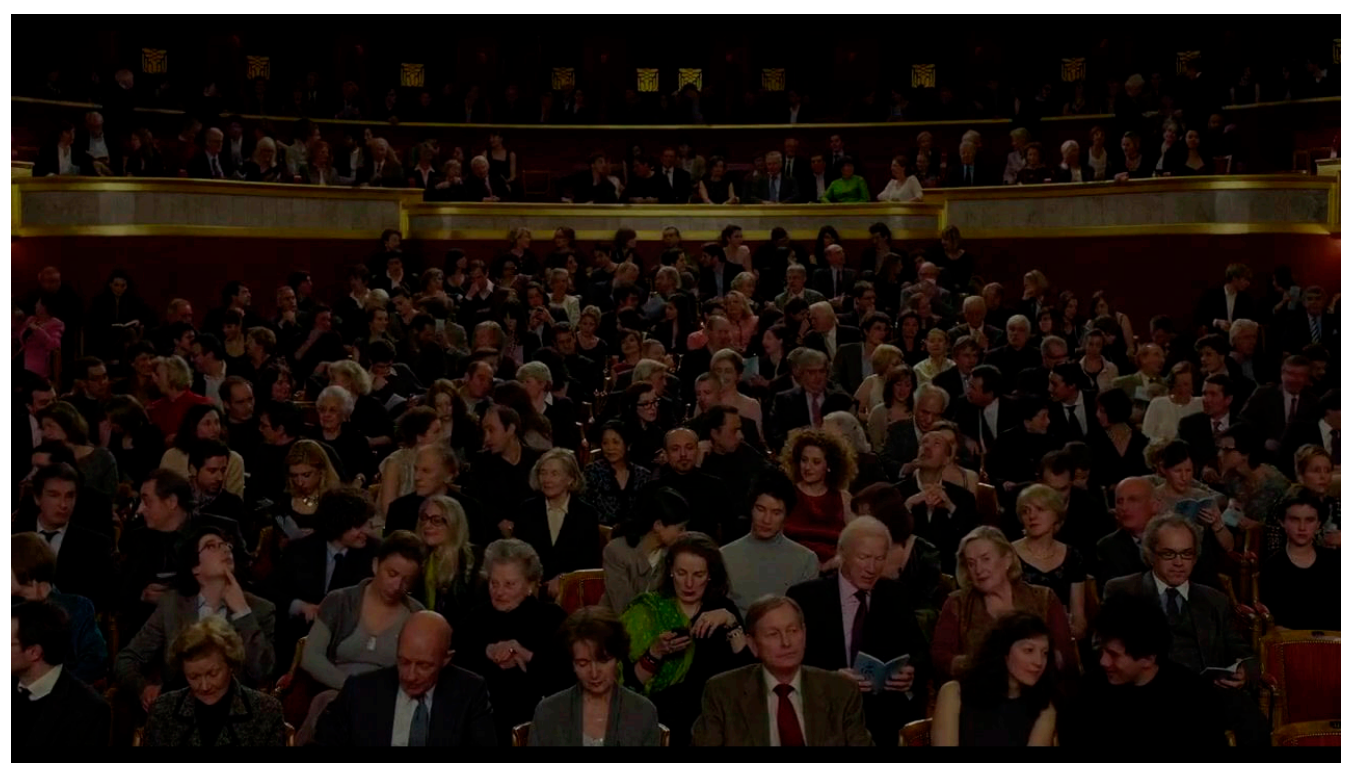

Figure 2. The story of Georges and Anne begins.

More recently, Milosz Paul Rosinski applies Jean-Luc Nancy's work on cinema, the body, and ethics specifically toward a theory of death in Haneke's Amour. Noting the significance of Haneke's oeuvre in the context of the 'New French Extremity's' violent and brutal cinema, Rosinski also detects a new and divergent trajectory in Amour: "The film marks a move from transgressive elements in Haneke's cinema rooted in disturbing visual violence to transgression understood as the shared responsibility of the viewer for the intimate other, and in more visceral terms as sharing pain." ([18], p. 181). Such a reading of the film shares much with what Stoehr and Wheatley have articulated about the ethical reflexivity of Haneke's films, but it is also dramatically tied to a Nancean conception of touch: "Touching acts as a mechanism of bridging the bodies in contact and sharing suffering." ([18], p. 193). In this way, Rosinski theorises death around the experience of "sharing pain" through the contact established by touch between the film's characters and also between the audience and those characters. He explains: "The touching of our eyes with the eyes of Anne and Georges and the embodied contact that evolves through the cinematic space allow for the immanence of our sense of understanding dying. Not only are Georges and Anne engaging in a relation of touch, but also the viewer and the film are in touch as a form of ethical contact." ([18], p. 192). Because viewers know from the outset of the film that Anne is dead, the film is then experienced as an extended and painful meditation on the power of touching another and the profound effects from the loss of that touch. Rosinski writes: "Through kaleidoscopic punctuations of pain, sorrow and reflection the viewer experiences the resistance of Georges towards the narrative pull of death in the omnipresence of a situation of care-giving without the prospect of alleviation. An intensified experience of extremity is produced through an enduring situation in which pain punctuates, rather than, happens, as a consequence of an event." ([18], p. 190). Thus, Rosinski concludes that the form of presence created by this "intensified experience of extremity" means that Amour provides well for Nancy's notion of death as the blind spot-“a way of looking through which we have to look but that is not seen itself." (Quoted in [18], p. 184). With his Nancean reading of Amour, Rosinski helps to provoke the essential question of this essay-indeed Haneke's 
own question-"How do I cope with the suffering of a loved one?" With Rosinski, we can esteem the great value of experiencing the birth to presence of this Nancean blind spot, but the wonder of seeing death afresh cannot provide us with a fully ethical response to it. Where should this transformative experience of "sharing pain" lead? With these contributions factoring in to our encounter with Amour, we can now focus on the question of authenticity and a proper ethic of death.

\section{Heidegger on Death: Anxiety, Resoluteness, and Solitude}

Bookended by two cataclysmic world wars and the new forms of mechanized death they introduced into the world, Heidegger's concern for authenticity led him to disturb the moral quietism of his day with the inescapable question of death. He describes at length the process by which the "they-self" (i.e., a mob mentality or group-think) succeeds in continually holding the thought of death in abeyance. Heidegger understood the greatest challenge to living an authentic life in the modern era to be what he calls, "the constant tranquilization of death." He reflects: "At bottom, however, this is a tranquillization not only for him who is 'dying' but just as much for those who 'console' him. And even in the case of a demise, the public is still not to have its own tranquility upset by such an event, or be disturbed in the carefreeness with which it concerns itself." ([19], p. 298).

Rather than dispel and avoid the anxiety produced by the thought of our own deaths, Heidegger hoped to recover such anxiety and make it productive for our lives. While we often worry over the manner of our death (our "demise" for Heidegger), he focused on the thought of our death's surety, the consideration of its brutal inevitability: "Anxiety in the face of death must not be confused with fear in the face of one's demise. This anxiety is not an accidental or random mood of "weakness" in some individual; but, as a basic state-of-mind of Dasein, it amounts to the disclosedness of the fact that Dasein exists as thrown Being towards its end." ([19], p. 295) ${ }^{7}$. In other words, authentic existence is fully living in the anticipation of life's end ([19], p. 286) ${ }^{8}$. Therefore, anxiety is unavoidable and yet also not to be resisted, for it is the natural response to a basic acknowledgement of the two overriding pressures on our existence, namely the fact that we find ourselves thrown into this life (both in time and place) and that our existence is thus directed toward its end. While we can never truly accept our condition, Dasein embraces this anxiety as the ground of its persistent and existential defiance of impossibility and nothingness. For this reason, Heidegger ultimately concludes that, "Being-towards-death is essentially anxiety." See Figure 3 ([19], pp. 310-11) ${ }^{9}$.

7 He further elaborates on the distinction between anxiety and simple fear of death: "Thus the existential conception of 'dying' is made clear as thrown Being towards its ownmost potentiality-for-Being, which is non-relational and not to be outstripped. Precision is gained by distinguishing this from pure disappearance, and also from merely perishing, and finally from the 'experiencing' of a demise."

8 Heidegger outlines three concrete realities of death that constitute Dasein: each person must own their death, death is an indefinite certainty for us all, and nothing supersedes the significance or priority of death for us.

9 For the fuller context, consider how Heidegger closes his section on 'being-towards-death': "In anticipating [zum] the indefinite certainty of death, Dasein opens itself to a constant threat arising out of its own 'there.' In this very threat Being-towards-the-end must maintain itself. So little can it tone this down that it must rather cultivate the indefiniteness of the certainty. How is it existentially possible for this constant threat to be genuinely disclosed? All understanding is accompanied by a state-of-mind. Dasein's mood brings it face to face with the thrownness of its 'that it is there.' But the state-of-mind which can hold open the utter and constant threat to itself arising from Dasein's ownmost individualized Being, is anxiety. In this state-of-mind, Dasein finds itself face to face with the 'nothing' of the possible impossibility of its existence. Anxiety is anxious about the potentiality-for-Being of the entity so destined [des so bestimmten Seienden], and in this way it discloses the uttermost possibility. Anticipation utterly individualizes Dasein, and allows it, in this individualization of itself, to become certain of the totality of its potentiality-for-Being. For this reason, anxiety as a basic state-of-mind belongs to such a self-understanding of Dasein on the basis of Dasein itself. Being-towards-death is essentially anxiety. This is attested unmistakably, though 'only' indirectly, by Being-towards-death as we have described it, when it perverts anxiety into cowardly fear and, in surmounting this fear, only makes known its own cowardliness in the face of anxiety." 


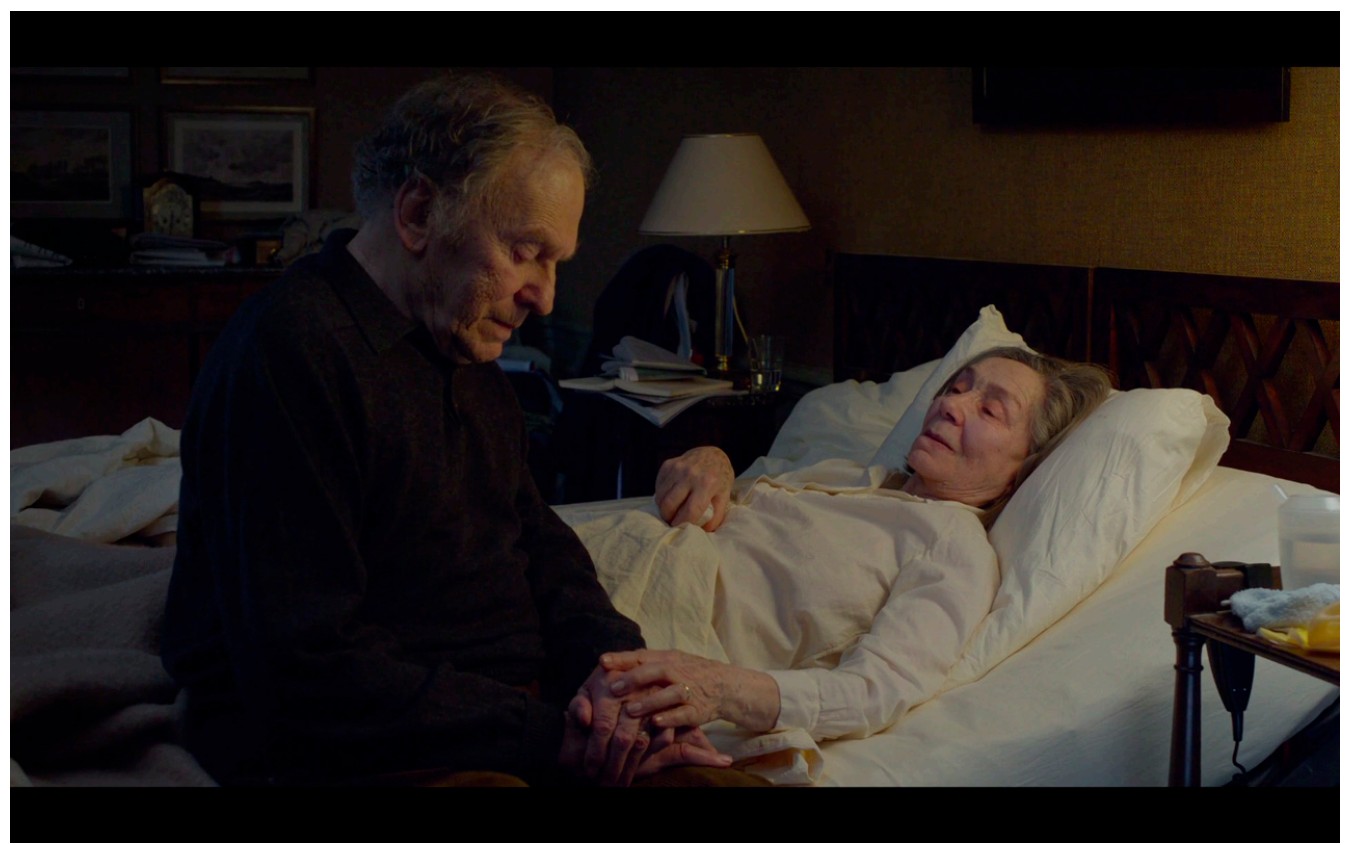

Figure 3. Georges and Anne anticipate her death.

Admittedly, if misery loves company, then, for Heidegger, company renders misery over death unproductive and impotent. That is why the individual must come radically close to the thought of their own death, and cinema offers unique possibilities for doing so when it imparts anxiety and rejects the comfort of the "they-self." When we access tragedy in film and vicariously experience the absence of some character, we are invited to resist the "constant tranquilization of death" and escape our own numb association with death itself, for in Heidegger's description, anxiety is an end point that must be preserved. From this conclusion, Heidegger develops the imperative of "resoluteness," or what commentator George Pattison renders: "resolute running ahead towards death." ([20], pp. 29-31). Resoluteness is facing death with determined consideration of one's own being; holding up death as the "possibility of impossibility" ever before us. For Heidegger, then, the struggle to be more present to our own lives stems from being able to face our mortality with resoluteness and the reward for doing so is our very freedom. Heidegger again:

We may now summarize our characterization of authentic Being-towards-death as we have projected it existentially: anticipation reveals to Dasein its lostness in the they-self, and brings it face to face with the possibility of being itself, primarily unsupported by concernful solicitude, but of being itself, rather, in an impassioned freedom towards death-a freedom which has been released from the illusions of the 'they,' and which is factical, certain of itself, and anxious. ([19], pp. 310-11).

Such are the conditions, according to Heidegger, for experiencing existential freedom.

Dietrich Bonhoeffer-an important interlocutor that we will return to later-engages with Heidegger's thought deeply. While Heidegger was all too quick to dismiss the insights of theology and saw it as merely another "metaphysics of death," theologians would do well to not return the favor ([20], p. 22). For his part, Bonhoeffer took up the topic of Heideggerian inter-subjectivity in his habilitationdisseration-published as Act and Being - and in his inaugural lecture as a new professor at Berlin University. In the latter, he articulates quite perceptively Heidegger's theme of resoluteness: "In the summons of conscience Dasein takes its guilt upon itself and comes to wholeness by entering into resoluteness to death and in that way finding itself. Dasein seizes its most authentic possibility, its most authentic existence, by coming to itself and in this way understanding itself." ([21], p. 395). Resoluteness provides Dasein some measure of freedom from the illusions and distractions of the 
group, because as it seeks to establish a solitary attentiveness to "being-towards-death" in each case. Simon Critchley reflects on Heidegger's resoluteness and helpfully clarifies that, "anticipation does not passively await death, but mobilises mortality as the condition for free action in the world." He continues:

This results in a hugely important and seemingly paradoxical thought: freedom is not the absence of necessity, in the form of death. On the contrary, freedom consists in the affirmation of the necessity of one's mortality. It is only in being-towards-death that one can become the person who one truly is. Concealed in the idea of death as the possibility of impossibility is the acceptance on one's mortal limitation as the basis for an affirmation of one's life.

So, there is nothing morbid about being-towards-death. Heidegger's thought is that being-towards-death pulls Dasein out of its immersion in inauthentic everyday life and allows it come [sic.] into its own. It is only in relation to being-towards-death that I become passionately aware of my freedom [22].

Resoluteness, then, becomes Heidegger's ethical response to death's certitude and the gateway to existential freedom. For those willing to face the grim truth of their own death, it becomes the measurement of authenticity in life. It is not enough to think one's death, but in resolute acceptance of it, Dasein anticipates death in each moment and season. Resoluteness, then, becomes a positive and affirming stance to life. We do this by turning inward, fortifying the self, and cultivating within ourselves a resignation toward the inevitable. Solitude frames our embrace of this resignation and protects our resolute stance toward death. Resoluteness generates in us an openness to receive what life has for us. We will return to each of these thinkers to lesser or greater degrees throughout the essay. The overriding concern, then, for authenticity in our encounters with film privileges the possibility of thinking and facing death. Let us now explore how this takes place around the question of love amid loss in Haneke's recent masterpiece.

\section{Facing Death in Haneke's Amour}

Throughout his cinematic career, Michael Haneke has pushed the limit of what cinema can do with anxiety, fear, and guilt. Films such as Funny Games, Caché, and The White Ribbon take the cinematic experience of anxiety to an almost impossible limit—daring the viewer to even attempt to redeem the event. Haneke executes his cinematic projects in, it seems, exactly the direction that Heidegger understands existential freedom to work. He confronts the viewer with the uncanny and impolite realities of human fragility and the sheer horror of "being-towards-death." Amour is no exception in this respect ${ }^{10}$. With considerable cinematic force, he puts the individual in imaginative isolation, creating an emotional distance from the film that allows for intense self-reflection and disassociation from a "they-self" experience of it. Audiences cannot easily identify with one character over another because the narrative unfolds in a purely observational and almost detached manner. We feel ourselves merely spectators at best and voyeurs at worst. As we witness the private terror of this couple and their degradation in the face of crippling health challenges, Haneke puts our capacity for empathy to an extreme test. Because Haneke does not shy away from documenting the depressive realities of Anne's diminishing health and the rapid loss of their connection to one another, we should see this film as a proving ground for Heidegger's notion of resoluteness in the face of death. Haneke's

10 Reflecting on The White Ribbon and Amour [23,24], Stoehr explains: "Haneke's two most recent films are intriguingly different from one another in that The White Ribbon (Das weisse Band: Eine deutsche Kindergeschichte, 2009) focuses on a collective sense of nihilistic anxiety and despair while Amour (2012) centers upon a far more personal and private sense of the same. In the end, however, both films indicate, perhaps far clearly than any of his others, that Haneke's dark vision is propelled by a very humane interest in the possibility of overcoming the negative forces in our lives." Stoehr, "The Anti-Nihilism of Kubrick and Haneke." 
restrained choices make this meditation on love in the face of death directly philosophical. It is not, however, flatly ethical in the sense we might expect and not principally concerned with Georges's unexpected outburst of violence. Because Georges and Anne are both victims of their mutual suffering, neither can escape what Grundmann calls the "test of their love." [3]. Consider the following moments as standing in defiance of Heidegger's resoluteness and its promise of freedom (see Figure 4).

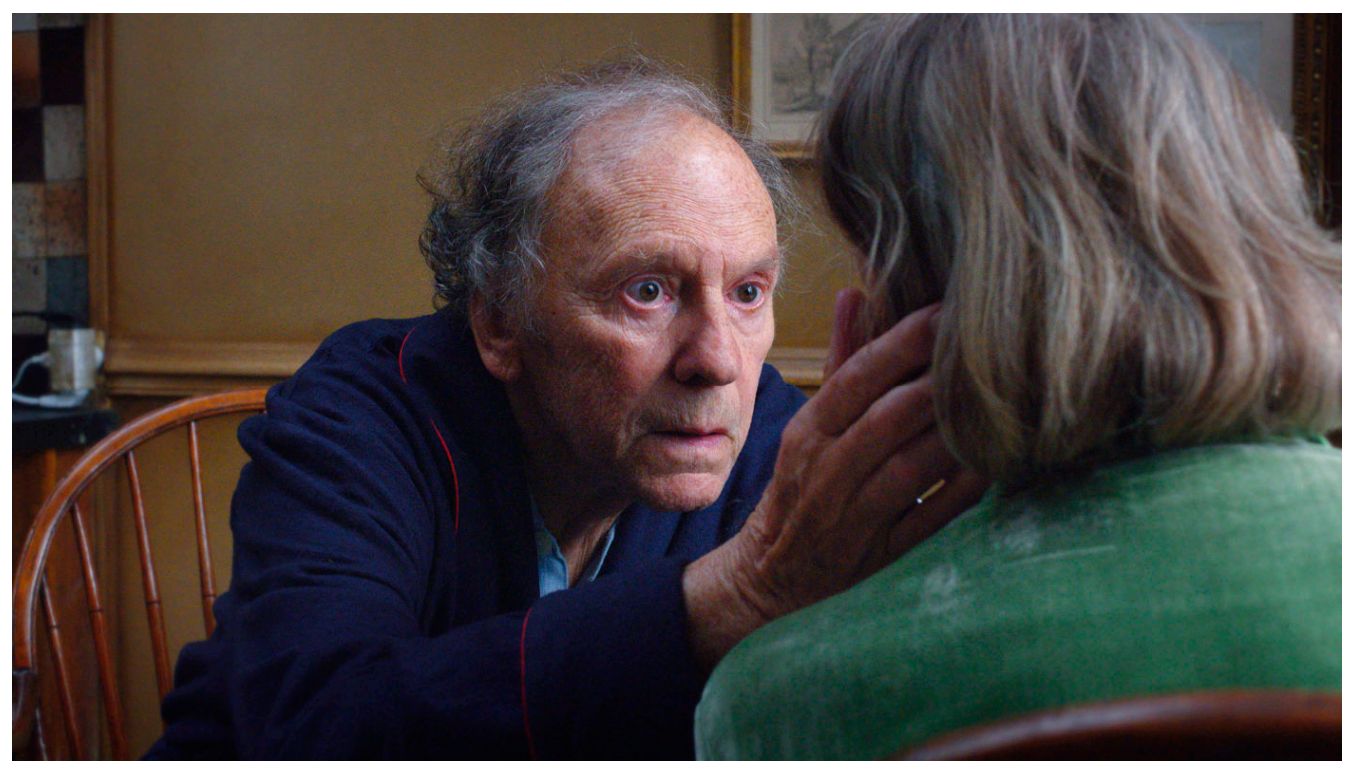

Figure 4. Georges begins to lose touch with Anne.

Though we often meet them in their beautiful Paris apartment, we rarely see Georges and Anne leave it. The quaint interiors seem to then amplify the horror of what happens to them there. Stoehr describes the film's setting as "claustrophobic" in the way that it swallows the private lives of the characters: "Haneke shows us in graphic terms-and in a slow, deliberate, haunting tempo of montage-the solitary challenges and horrors of their daily existence. Most of the movie is set in the couple's apartment and the world beyond is glimpsed only through windows and doorways." [14]. The tragedy unfolds first within their modest kitchen around the breakfast table. The initial sign that something is not right emerges from a sudden gap in their morning conversation. As Georges blathers on with some insignificant news from a friend, he eventually notices that his wife is no longer with him in the moment. She sits there motionless, blankly starring at nothing at all. As the awkward moment lingers on, Georges becomes unsettled and seeks to bring her back. When Anne does regain consciousness, she has no recollection of the lost time. Not quite sure what has happened, the two return to their breakfast, but in doing so, Anne attempts to pour her tea and in missing the cup entirely signals that she is losing control of that side of her body. As Georges and Anne discover the first signs of her stroke and impending decline, we anxiously anticipate what will follow this horrible prelude.

A particularly quiet meal takes place in the early days of Anne's experiencing the effects of her stroke and prior to her next, more massive and debilitating stroke. At the table, Georges seems to eat hurriedly, as if this moment represents an all too brief respite from the ordeal of caring for his wife. Interrupting his somber dinner, Anne asks Georges to retrieve their photo albums. She wants to recall some memory from the early years of their marriage. Initially, Georges wonders why she would want them at that moment. He complies with her request but is clearly annoyed. The burden of caring for his wife as her health deteriorates is beginning to settle in for him, and the hope that she might come through these difficulties dissolves day by day. In this difficult scene, the pair of elderly lovers becomes momentarily unrecognizable. The patience and forbearance they have demonstrated with one another evaporates. They seem little more than strangers, barely able to tolerate one another. She reminisces over their treasured family photos, but he looks on in detached bewilderment. It is only a moment 
in the film but it bears a revelation. Anne knows her care is taking its toll on him. Though she has suffered the stroke, it seems at this point that Georges is the one who has lost touch. The weight of the moment is lost on him. Anne offers the opportunity for reconnection and shared memory, but his frustration and fatigue prevent him from seeing it. Anne waits for him and he looks on with some indiscernible combination of sadness, guilt, and detachment. They miss each other in this moment, but the audience feels the disparity between what they have and what they will lose (see Figure 5).

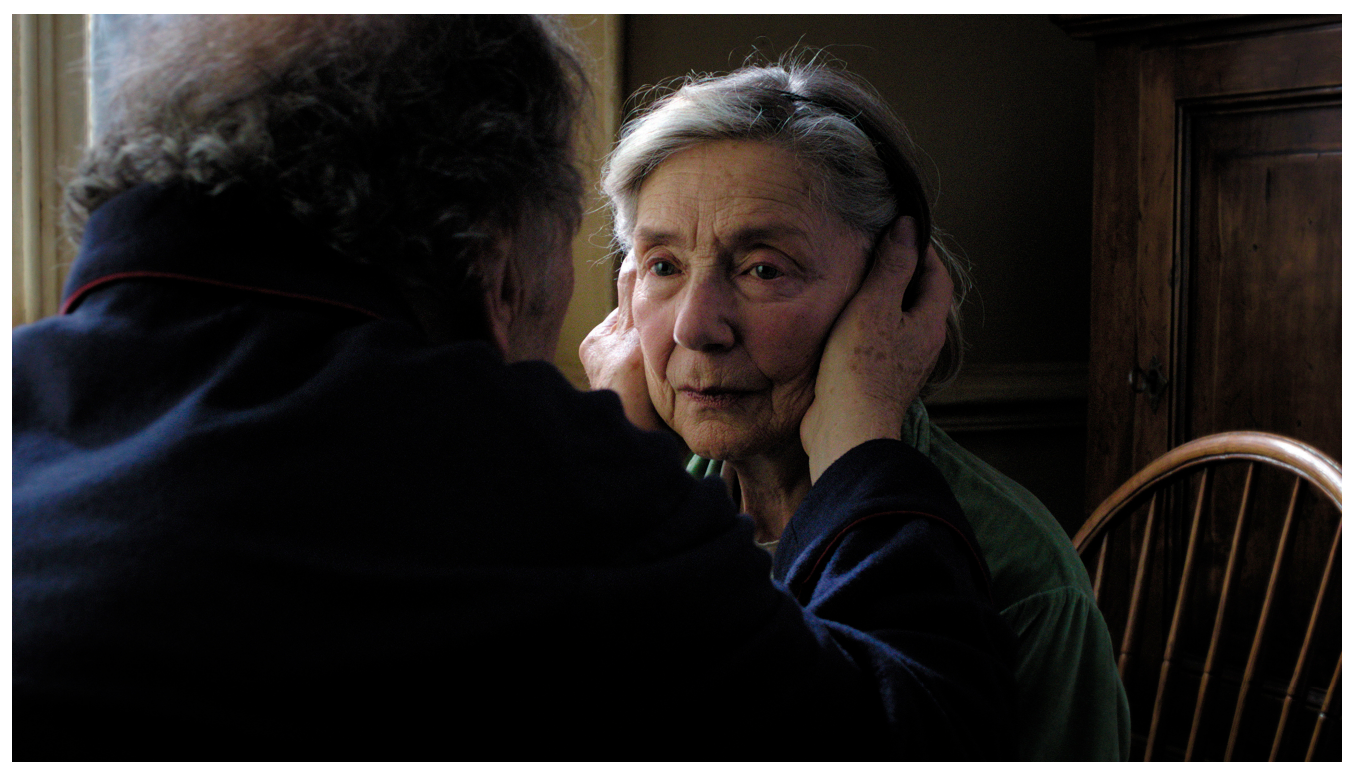

Figure 5. Anne begins to slip away.

While wearing fear of the worst, Georges and Anne persevere to keep their normal routines. Of this period, Grundmann notes: "We get to witness in painstaking detail Georges's awkward and clumsy attempts at propping up his wife in bed, helping her walk, lifting her off the toilet, or turning her from one side to the other in bed to change her diapers, all of which he performs ardently, while full well recognizing the danger of becoming paralyzed himself by the pall of hopelessness and the tyranny of fear." [3]. Recall, for instance, the particularly unsettling scene in which Anne sits at her piano and gives a seemingly beautiful performance for Georges. The tender nostalgia of the moment is, of course, crushed when Georges reaches back and cuts off the stereo. At this point, the unbearable silence of their lives returns and the weight of the struggle intensifies. Juxtaposed alongside such scenes of domestic disquiet, we encounter the unraveling of Georges's resources to deal with their predicament. He struggles in his own ways, namely in the form of terrifying dreams, including one where he must answer a mysterious knock at the door in the middle of the night. We witness the shock and fear it brings on him, and when he awakes in bed next to Anne his screaming alerts us to the deep grip that his insecurities and fears about safeguarding his wife have on him. In the midst of such internal unease and anxiety, we cannot help but also note that the nightmares that terrorize Georges do not compare with the horrors that he finds when waking. The life he knew with his wife has become for them both a waking nightmare-a prolonged and painful disintegration of what they held dear (see Figure 6). 


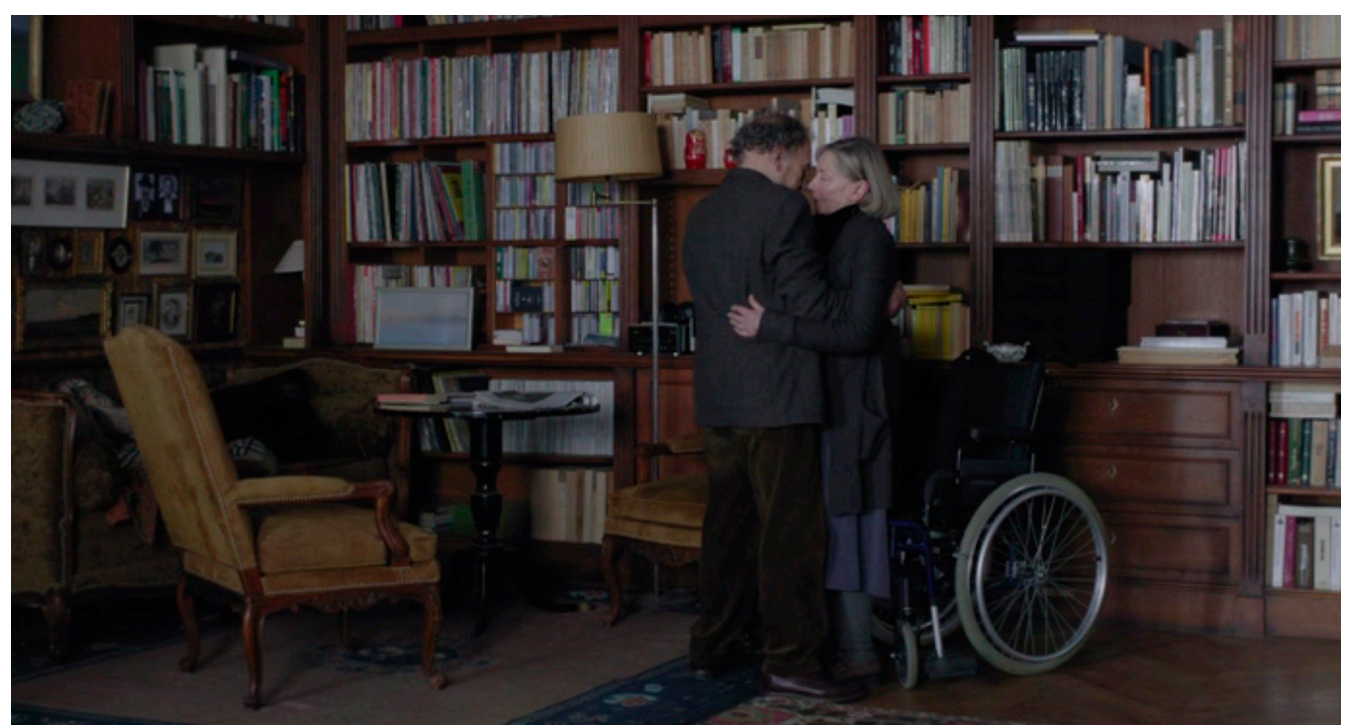

Figure 6. Georges and Anne struggle through their difficult dance of grief and care.

As the story creeps toward its terminus, the cruel juxtaposition of an earnest offer of reconnection and the intractable inability for such builds to a horrific crescendo. By this point in the film, Anne has lost all ability to communicate, cannot leave her bed, and incessantly wails and moans from the pain. Georges has promised that he will not abandon her to full-time care or the hospital, and in keeping his solemn promise, he has alienated or dismissed all forms of support for Anne. They have reached the limits of despair and incredulity at what their lives have become. In this state, Georges attempts to soothe his wife once more. At her bedside, he recalls a tender story from his childhood-the memory of his choice to protect his own mother from the truth about how much he despised his time at a summer camp. The details of this memory reveal nothing new for us about Georges, but the care in which he dredged up the tale demonstrates the lengths he will go to in trying to touch his wife's heart once more. The story has its intended effect. Anne's moaning has ceased, and in that moment of calm, Georges takes a pillow from their bed and smothers her.

This sudden and unexpected violence discloses little more than Georges's agony and desperation over his wife's misery. The sheer horror of Georges's erratic choice to kill his wife and end her pain leaves us with more questions than answers. This decisive act by Georges parallels other shocking and climatic outbursts of violence in Haneke films (e.g., Code Unknown or Caché), but, the conclusion of Amour is strikingly different ${ }^{11}$. In this instance, the final rupture of violence is extreme but not arbitrary, decisive but not flatly cruel. Amour is, perhaps, the most extreme fulfillment of this narrative technique for two reasons. First, the audience knows the outcome from the beginning. In the opening scene of the film, we witness the barricaded bedroom tomb of the female lead, so that from the outset, her eventual death is made clear. Whatever surprise or twist ending, then, that remains for the audience must

11 Ben McCann situates these violent outbursts in Haneke's broader use of violence: "Known for the brutal psychological and physical violence of films such as Benny's Video (1992) and the two versions of Funny Games (1997, 2007), Michael Haneke offers viewers critical and ironic documents of social disaffection, alienation and interpersonal abuse that resist easy absorption or consumption. Yet, although addressing the murder of children, bodily dismemberment, graphic suicide, rape, sadism and brutality, Haneke's films eschew the direct representation of explicit violence in favor of more subtle, minimalist and complex depictions. Manipulating sound, off-screen space and the long take, his films explore rather than expose and thus offer an analysis of violence that interrogates its complexity: violence in Haneke has many forms, functions and incarnations, and ... [his films] are as much about questioning what constitutes violence as they are investigations into its manifestations, attractions or mediations. While violence shocks and erupts as a climactic event in Haneke films (the father's death at the beginning of Le temps du loup, The Time of the Wolf, (2003), the murder of the young girl in Benny's Video or the child in Funny Games) ... it is never depicted as an isolated incident but is yoked to larger social, political and ethical issues." [25]. 
concern the circumstances that lead to her death. Secondly, while Georges's desperate choice comes as a complete shock to the audience, the conclusion of Amour introduces a merciful violence, which has not been witnessed in Haneke's work before. In this sense, the climactic outburst of violence here cannot be seen as simple, uncomplicated tragedy.

In light of such an unforeseeable outcome, the brilliance of Haneke's documenting Anne's slow demise shines in the difficult questions posed along the way. Without explicitly defending Georges's choice, Stoehr redirects to the more significant fact that it is clear that "Georges's deep love for his wife has made it unbearable for him to continue seeing her fade painfully into a mere semblance of her former self. It is far from being a selfish or even nihilistic decision, especially given all that we have witnessed of his selfless dedication up to this point." [14] $]^{12}$. Thus, we must reckon with questions such as these: How can we so easily take for granted the contact we have with our loved ones? Why is it so inexplicably hard to reach one another? And can we ever really know one another? These kinds of concerns press down on us. They deflate our every attempt to bring the dire circumstances to some meaningful and optimistic end. They obliterate our confidence that we could keep at arm's length a film such as this. By testing the limits of our empathy with the screen, Amour exposes the mystery of love, especially love in the liminal space between life and death. By orchestrating this symphony of grief, Haneke's Amour invites us to consider the limits of our own capacities for facing death. If we carefully attend to the ethical self-reflexivity of Amour, we can have a greater appreciation for the extent of human weakness that is displayed so poignantly in Georges's love for his wife. Whatever we make of Georges's choice to end the life of his wife, we must consider it a mutual death. He may still be living after Anne is gone, but what is left of life for him? In a sense, he dies with her. Her death means the utter loss of his sanity, his peace of mind, and any purchase in the world of home and family they knew together. Let us return to Haneke's comments that opened this essay: "To find dignity in suffering is only possible through love and compassion. That is most difficult. As love is a difficult thing. It is not given to everyone." Georges portrays the risk of love that Haneke intimates here. He shows us that in order to love to the limit one must sacrifice one's own defenses against death. In this way, Amour ultimately betrays Heidegger's ethic of resoluteness and decisively shatters solitude as a therapeutic category for thinking death. Such a contribution deserves ample consideration, and the theologian Dietrich Bonhoeffer will aid us in these efforts (see Figure 7).

12 In defense of Georges, Stoehr draws a comparison to the detachment of their daughter. He continues, "The film steers us toward compassion for Georges's acceptance of euthanasia as the best possible solution. While Haneke intentionally uses moral ambiguity in many of his film narratives, it is in some cases a merely surface-level ambiguity ... It is far from being a selfish or even nihilistic decision, especially given all that we have witnessed of his selfless dedication up to this point ... An affirmation of life goes beyond the mere prolongation of insufferable biological existence. If there is room for moral condemnation at the end, then it would be the condemnation of Georges's rather callous, self-absorbed daughter who, in the final image of the movie, enters their empty apartment to consider the awful twilight of lives she barely knew." 


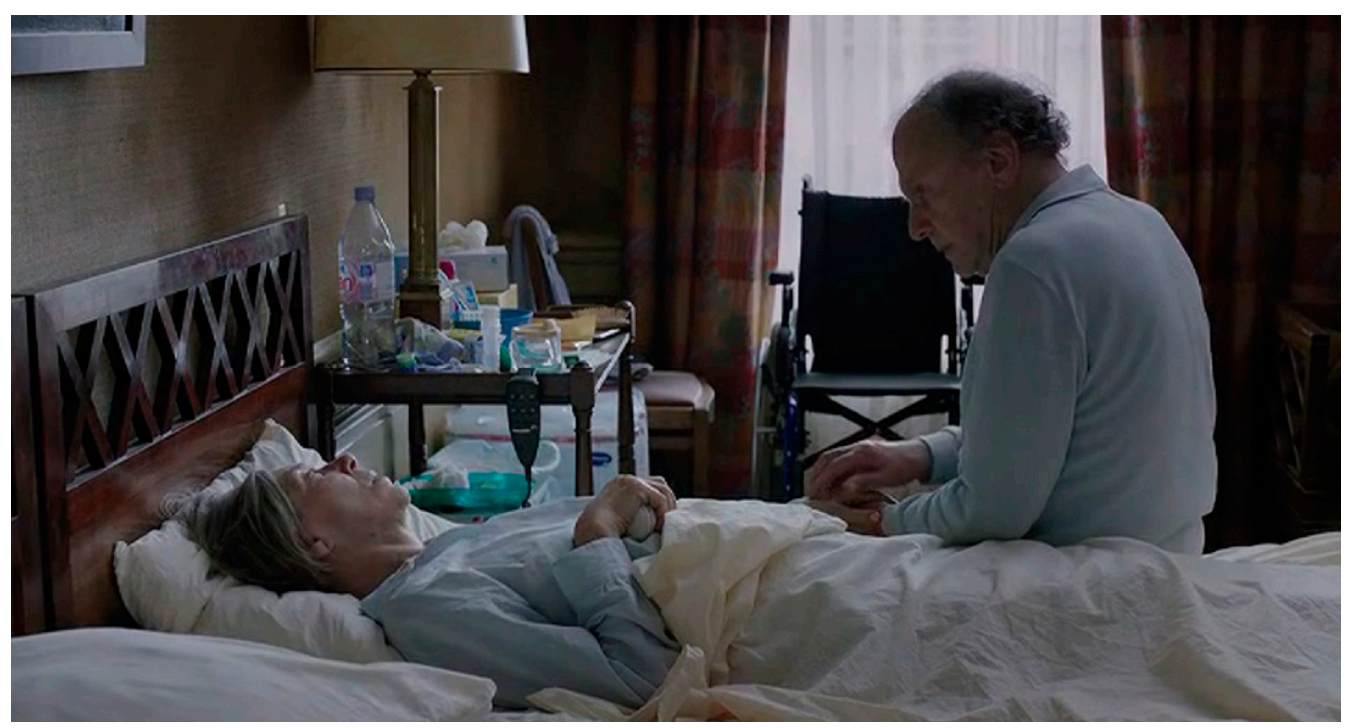

Figure 7. The couple reaches a breaking point.

\section{A Theology of Death for Haneke's Amour}

We now turn to a theological proposal for accessing the existential profundity of Haneke's Amour. A theological response to what we experience in Amour must also entail a critique of Heidegger's ethic of resoluteness, which unfolds in two movements: first, by exposing the superficiality of Heidegger's account of resoluteness and secondly, by offering a positive substitute for resoluteness. From the outset of this critique, it should be noted that Heidegger's ethic of resoluteness has not been universally received, and that resistance can be found in theologians and other continental thinkers. Here for instance, we will consider the way in which a modern theologian and a contemporary philosopher advance the critique. Returning to Critchley then, consider this brief but poignant criticism of Heidegger's overall approach:

Despite its baroque linguistic garb, Heidegger's analysis of being-towards-death is exceptionally direct and powerful. However, it is open to the following objection. Heidegger argues that the only authentic death is one's own. To die for another person, he writes, would simply be to 'sacrifice oneself.' To that extent, for Heidegger, the deaths of others are secondary to my death, which is primary. In my view (and this criticism is first advanced by Edith Stein and Emmanuel Levinas), such a conception of death is both false and morally pernicious. On the contrary, I think that death comes into our world through the deaths of others, whether as close as a parent, partner or child or as far as the unknown victim of a distant famine or war. The relation to death is not first and foremost my own fear for my own demise, but my sense of being undone by the experience of grief and mourning [22].

Critchley's position to represents a social critique of resoluteness. From this line of thinking, Heidegger's appeal to resoluteness and its attendant fascination with solitude represents an untenable and inaccessible ideal. His thought seems detached and distant from the actual experiences of people in community, especially the relationships between loved ones. We may hope that individuals would contemplate their own death early in life and begin facing it from that origin point, but as most would agree, grief and loss meet us first. Our contemplative journey with our own mortality is almost always interrupted by the sudden, unexpected loss of a loved one. Another, and perhaps more prolific, critic of Heidegger corroborates Critchley's position. Jacques Derrida writes in "The Taste of Tears" that, "To have a friend, to look at him, to follow him with your eyes, to admire him in friendship, is to know in a more intense way, already injured, always insistent, and more and more unforgettable, that one of 
the two of you will inevitably see the other die." ([26], p. 107) ${ }^{13}$. Most of life with our loved ones is spent in unconscious-and sometimes fully conscious-abeyance of this fact, but Haneke's Georges puts a face on the feeling for us.

From a parallel but distinctly theological vantage point, Bonhoeffer embraces the risk rooted in love and friendship and attacks the untenable character of Heidegger's account of solitude in resoluteness. He summarizes Heidegger on solitude thus: "The person gains command of the world by elevating himself into a tragically isolated individual. The person remains alone, understanding himself from himself; being in the world has no meaning for one's authentic self-understanding. Ultimately the person himself answers the question about the human being." ([21], p. 396). Bonhoeffer had utilized Heidegger's phenomenology in Act and Being as a means to overcoming the dominance of transcendental thought in German philosophy, but he also responded to the question of inter-subjectivity raised by Heidegger's Dasein with a dynamic account of Christ's outward pull of the individual into the sociality of Christian community ${ }^{14}$.

While Bonhoeffer allows for several of the considerations that frame Heidegger's description of "being-towards-death," there is much he will not allow ${ }^{15}$. They shared concern over death, namely the return to concrete experience and the acknowledgement of anxiety, but they critically differed regarding the purpose and trajectory of this anxiety [28]. Heidegger, it seems, would seek terms of peace from death, but Bonhoeffer would rather see death defeated and finally overcome. In particular, Bonhoeffer acknowledges death as the limit to our being in the world and the anxiety that this realization induces, but he firmly rejects these implications of Heidegger's response: first, that possibility and potentiality-for-being can provide the grounds on which we assess our mortality; second, that the thought of death sentences us to solitude and isolates us from others; and third, that resoluteness gives the best guarantee of freedom. Bonhoeffer makes clear his departure from Heidegger with respect to his categories of "possibility" and "potentiality" for Dasein. In a paraphrase of Act and Being, Bonhoeffer asserts emphatically in his inaugural Berlin lecture that, "the concept of [pure] possibility has no place in theology and thus no place in theological anthropology." ([21], p. 403) ${ }^{16}$. While he appreciates the return to the concrete realities of Heidegger's phenomenology, there can be, for him, no discussion of "possibility" or "potentiality" outside the summons of divine revelation. We do not have unfettered access to these on our own. For this reason, anxiety in the face of death renews in Bonhoeffer the question of obedience before God, what he recognizes in Heidegger as "the summons of conscience." He explains further:

The place where God attests himself must be the place from which the human being understands himself and at the same time the place where his unity is founded. This place, however, is obviously conscience. Here the human being knows himself to be summoned, called to accountability, judged, and justified. Here is God's gateway into the person;

13 Derrida reflects further: "From the first moment, friends become, as a result of their situation, virtual survivors ... Friends know this, and friendship breathes this knowledge, breathes it right up to expiration, right up to the last breath. These possible survivors thus see themselves held to the untenable." ([26], p. 173).

14 Wayne Whitson Floyd, Jr. summarizes Bonhoeffer's use of Heidegger in Act and Being thus: "His explorations of the Kantian definition of the limits of philosophy — and Hegelian and Fichtean idealism's constant transgression of the limits of genuine Otherness through the pretensions of reason-led Bonhoeffer to inquire into the phenomenological and ontological traditions. He was especially concerned with the problem of intersubjectivity in the philosophies of Edmund Husserl and Martin Heidegger, whose Being and Time was published in 1927, just after Bonhoeffer's work on Sanctorum Communio was complete. Throughout Act and Being, Bonhoeffer is arguing that what is needed is a form of theological thinking that takes seriously both philosophy's own repeated attempts to surmount its intrinsic tendency toward system, toward totality, and the reasons they must be judged a failure. He wished to clarify the extent to which theology can or cannot affirm transcendental epistemology's subject-object paradigm as appropriate for theological thinking that remembers the sociality of the Other, the ethics of difference-between humanity and God, as between one human being and another." ([27], pp. 10-11).

15 Pattison offers a helpful clarification here: “In light of the existential-ontological understanding of Dasein's being towards death that Heidegger in fact arrives at, it is hard to imagine any way of affirming some kind of post-mortem existence that would not undermine the entire structure involved in such a being towards death." ([20], p. 22).

16 He then enumerates no less than six reasons for this assertion. 
here we find the immediate connection with God. The human being is a person of conscience who understands himself out of the reflection on his own conscience in which God encounters him ([21], p. 400).

That Heidegger cannot relate "the summons of conscience" to an authenticity based on concern for the deaths of others remains Bonhoeffer's chief point of contention with him and the reason for his ultimate rejection of Heidegger's category of resoluteness. On this point, Bonhoeffer insists upon the ethical demand on the individual to acknowledge the divine address present in the suffering and death of the other ${ }^{17}$. For Bonhoeffer, being human means being in relationship with others, living in a state of mutuality and mutual address by God. We cannot understand ourselves apart from our relationships to others, and that sociality is inherently ethical. We demonstrate hospitality to divine otherness when we receive and reciprocate the other person before us. For Bonhoeffer, there is no true experience of solidarity or communion with others apart from the ministry of Christ, but the capacity to encounter one another in this way is given to us first by virtue of being made in God's image. We are created for the gift of love and the mutuality that love makes possible. Because this gift comes from outside ourselves, we cannot assume authority over our own potential, but instead we must acknowledge our need of others. We rely on this divine summons to support our sociality with one another and to provide the meaning that makes our lives more than merely the anticipation of death. In receiving this gift of love, we are also then free to live for the sake of others and renounce our fear of death through sacrifice and service to those that are suffering and dying or those who will. In this way, love-not death-determines the meaning of our lives.

In returning to Amour, we must ask: Can something like Bonhoeffer's notion of answering a divine summons be seen here as well? What can we make of Georges's desperate choice to end their mutual suffering? There are a few things about how Anne died we can claim with confidence. She did not die in hospital, because Georges chose to keep his promise to her and never let her return there. She did not die as the result of a grisly and natural deterioration, because Georges chose to abandon his shame and commit the unthinkable. We can see that he is tortured by this impossible choice. He cannot abandon his duty to care for his wife to someone else. He cannot bear to watch her suffer. He cannot leave her and he cannot free her. In the end, the only reason that this killing presents such a challenge to us is that these competing forces in Georges's love for his wife drive him to this excruciating paradox. They have reached this point because of love, and despite the horror of what occurs, love-not death-drives the outcome. Georges and Anne are bound together in life and in death by the mutuality of their love.

17 Dietrich Bonhoeffer was a German pastor and theologian, but he spent the last few years of his life languishing in a German prison for his participation in a conspiracy to assassinate the Führer until he was executed at Flossenbürg concentration camp on 9 April 1945. In his moment of deep distress, Bonhoeffer, in faith, turns his heart toward Gethsemane and the moment of Jesus Christ's deep distress and anguish. Earlier in his inaugural Berlin lecture, he had referred to this crisis point as being "given over to the death of Christ." In this way, however, he responds to the address of God with obedience; that is the obedience of faith, which leads him back to Christ. Trusting Christ from his prison cell means for him what it has always meant: that is, identification with the life of Christ. Identifying with his life means primarily his life in the world, climaxing with his Crucifixion and Resurrection. By virtue of the obedience of faith, then, Bonhoeffer is not preparing to die alone. Rather he is preparing to follow Christ into a sacrificial death, a death for others. Therefore, he is not alone; he is not imprisoned by his solitary death. Instead he prepares himself to know more fully, in the words of the Apostle Paul, Christ and "the power of his resurrection," and to "share his sufferings, becoming like him in his death." (Phil. 3:10) Like Paul, this sacrifice is for Bonhoeffer pure joy, and that is why we find little purchase in Bonhoeffer's late reflections for a self-description of his death as an overt martyrdom. With joy, Bonhoeffer can prepare for the end as a means to a greater freedom than Heidegger could envision. He describes this freedom in the poems he wrote from prison, in particular the irrepressible meditation within his poem "Stations on the Way to Freedom." In the final stanza entitled "Death," he writes:

Come now, highest of feasts on the way to freedom eternal,

Death, lay down your ponderous chains and earthen enclosures

walls that deceive our souls and fetter our mortal bodies,

that we might at last behold what here we are hindered from seeing.

Freedom, long have we sought you through discipline, action, and suffering.

Dying, now we discern in the countenance of God your own face ([29], p. 514). 
We must then return to the concluding scenes of the film, but with the recognition that there is so much more that could be said. Let us proceed through the final movements of the film to understand the cost of Georges's horrible choice. With a few subtle narrative choices, Haneke makes clear that the end of Anne means the end of Georges. We begin with the manner of his killing of Anne. It is not beyond the realm of reasonable speculation to see something of his identification with her death in the very manner of his killing. While George smothers Anne, at the same time he plunges his own head into the pillow on top of her face. Could this be taken to indicate the last gesture of intimacy and solidarity with his wife even in her death? Could it be that Georges wishes to die with her even though he cannot? It is not unwarranted to see this impulse to continue in his identification with her in that moment. Perhaps his actions intimate not only murder but also suicide (see Figure 8).

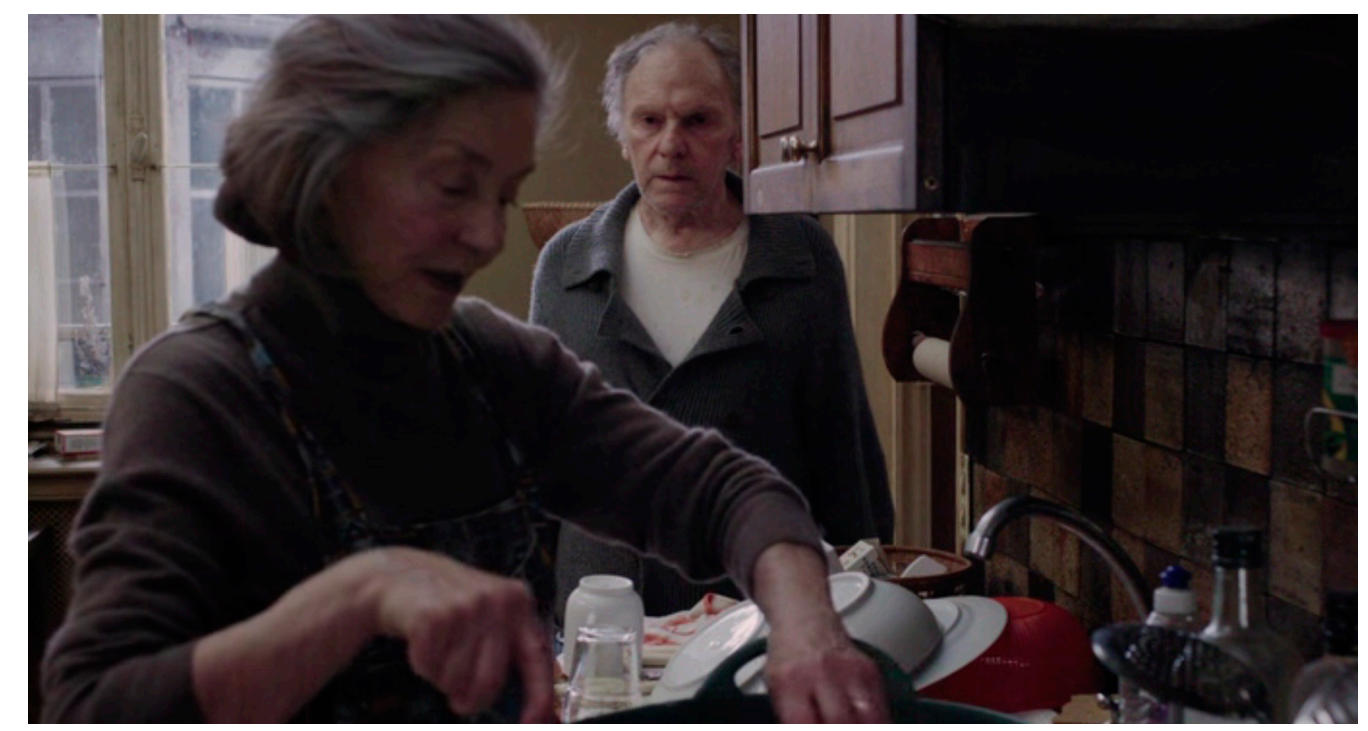

Figure 8. Georges has lost touch.

After she is gone, we next see Georges returning from a shopping errand. Is he capable of returning to normal life? Any attempt to appear as if he can still function in the world, however, is rendered null when he refuses to answer the telephone's ringing and continues preparing the flowers he has bought. Moments later Georges is selecting a dress for Anne and fortifying the bedroom as her last resting place. His final preparations conclude with the writing of a letter at their breakfast table. When a pigeon returns to the apartment, Georges attempts once more-in his disheveled and frail state- to capture it with a blanket and, once he has, he embraces the bird and tenderly strokes it. Returning to the table that evening, Georges relays the incident with the pigeon in a letter presumably to Anne. Despite the sense of routine in his actions, they betray a mental instability that begins to overtake Georges. At the close of these final portraits, we find Georges resting on his cot. He begins to hear the noise of dishes clinking from the kitchen, and when he investigates he finds Anne busy washing up from a meal. She is just as she was prior to the stroke. They put on their coats, and Georges follows her out of the apartment for the last time. The next time their apartment door opens we see their daughter returning to the home after the police have investigated and the apartment has been cleared of any trace of Anne's internment. Georges's brief but alarming hallucination is seamlessly fit into the final moments of the film and confirms what audiences no doubt suspect about him: in killing his wife, Georges has lost touch with reality. Haneke uses this moment to acknowledge the toll taken upon Georges for the horrible choice he faced. In freeing Anne from her suffering, he sacrificed his own sanity for her. It is for this reason that we must esteem her death a mutual end for them.

In Amour, love proves stronger than death because Georges is ultimately unable to free himself from Anne's death. Solitude, for him, is no sanctuary; resoluteness in the face of death remains a farce. Instead, they have given each other the utmost dignity. Sacrificial love-not resoluteness—becomes 
the testimony of their life together. Their mutuality binds them and traps them. But it may also grant them some measure of transcending death. Throughout the film, Georges has honored the wish of his wife to never return to hospital and has cared for her through each successively debilitating stage of her decline. He has witnessed her loss of memory, mobility, speech, and awareness. His beautiful and sophisticated wife has been reduced to incoherence, detachment, and unmitigated pain. In ending her suffering, Georges is acknowledging her vital worth and honor, but through death, he both seals off her dignity from further decline and destroys it. Though it drives him mad, Georges chooses to embrace the guilt of killing her over the shame of watching her struggle toward death. This irredeemable choice brings him to the edge of love's impossible demands ${ }^{18}$. While we affirm the irrepressible and selfless love that led him to that desperate place, a faithfully Christian response, in the end, cannot condone Georges's horrible choice. Indeed, "love is a difficult thing," as Haneke himself underscores, and in the face of immense suffering and death, love alone - even absurd, indefensible love-remains the only refuge from horrific loss and the grief that threatens to undue us. And yet, "It is not given to everyone." Despite even our best attempts, love remains an inexhaustible mandate, yet to be fulfilled: as St. Paul holds out in 1 Corinthians 13:7, "Love bears all things, believes all things, hopes all things, endures all things" ${ }^{\prime 19}$. Such a meditation is, no doubt, much more than audiences expected from the enigmatic and intractable director (see Figure 9).

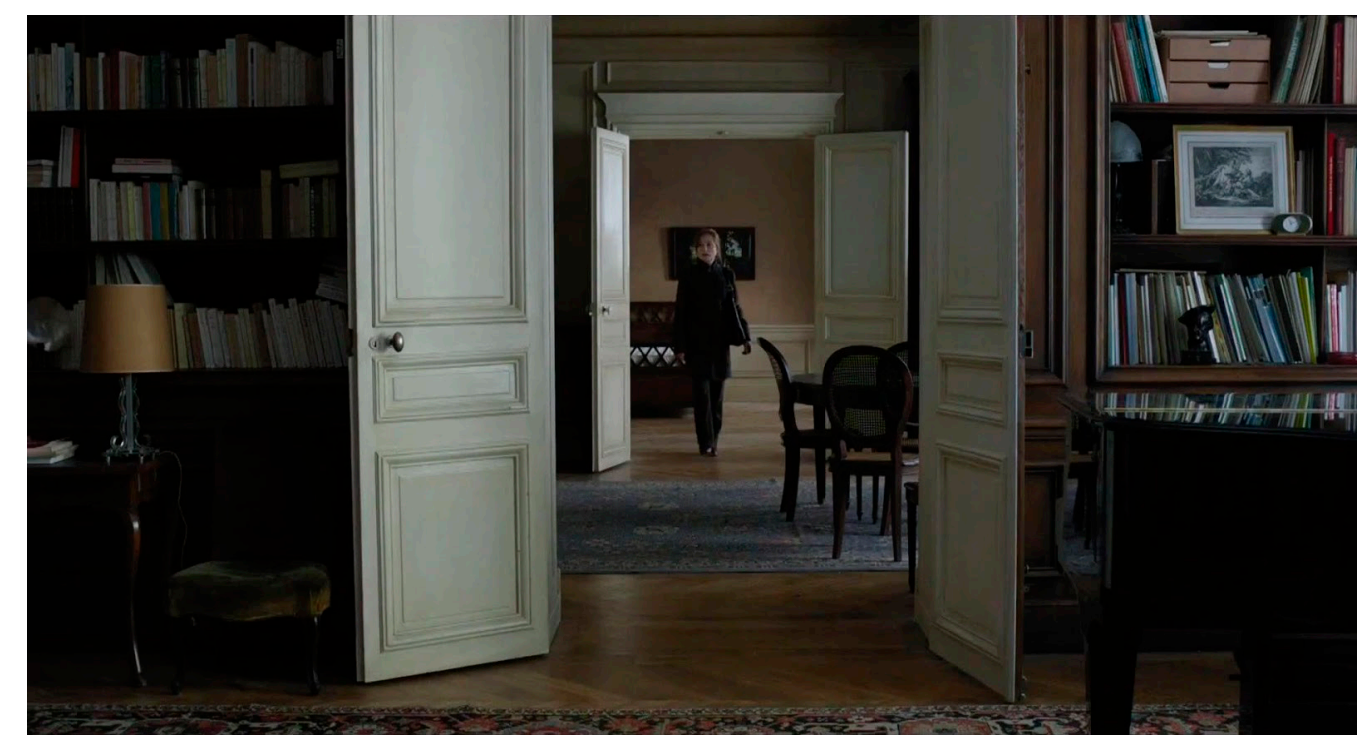

Figure 9. Georges and Anne's daughter visits their empty home.

The theological significance of Michael Haneke's Amour resides in making death real and oppressive for us once more. Haneke does this by thrusting Georges's impossible choice upon us. If we are gripped by the dreadfully paradoxical dictate of love in Amour, then perhaps we will also find in the film an unflinching and equally unshakeable affirmation that the bonds of love that we share in life will-for good or ill, for better or worse-be the same bonds we share in death. Amour stands as a protest to the polite notion that we might ever move on from the loss of our loved ones, especially the loss of a spouse. Thinking our own death cannot be done in isolation from thinking the death of the one we love. For all its austere depictions of the suffering of loss, Amour presents a humane and

18 In a similar fashion, film critic Mark Kermode concludes: "From this crucible of pain, Haneke and his cast conjure something paradoxically uplifting - a paean to marital devotion that avoids sentimentality like the plague while looking death in the face; calm, unblinking, heartbreaking-honest."[30]. Additionally, in his more than six minute review for BBC Radio 5, Kermode does not even mention the act of euthanasia in the film [31].

19 Revised Standard Version of the Bible, copyright (C) 1946, 1952, and 1971 the Division of Christian Education of the National Council of the Churches of Christ in the United States of America. 
poignant portrait of why in fact we must remember that we die and must measure the cost of love to live a life worthy of grief and mourning. While many will no doubt find it ironic that Heidegger provides us aid in giving this account of Amour-given his infamous associations with the Nazis and Haneke's concerted choice to expose the hidden traumas of that past in his films-these men share with Bonhoeffer an appreciation for the kind of anxiety that thinking death produces. Making such anxiety life-affirming and generative, however, is beyond what Heidegger himself can do. For this, Bonhoeffer proves exceedingly helpful. Can Heidegger's resoluteness enable us to love to the point of death and beyond? Is Heidegger correct when he states that death guarantees life? His response to the threat of death's isolation and alienation was to develop a resoluteness to it that might open us up to experience life as more concrete and meaningful because of death's limit. Amour stands in judgment on these very claims. Haneke's film mocks that attempt and yet it also suggests an ethic even more authentic than resoluteness and solitude. Amour reveals for us a greater force than death; love-self-giving, self-risking, self-shattering love-alone can lead us through death. Solitude, in resolute defiance of death, will never know the freedom that one experiences in truly loving another through their most extreme sufferings. Only the love that has sealed its fate to its beloved can know this freedom in action, or in the haunting words of Haneke himself: "What we're doing for another person is more important than what we're feeling for them."[6].

Conflicts of Interest: The authors declare no conflict of interest.

\section{References}

1. Michael H_Profession: Director. Directed by Yves Montmayeur. Prague: Crescendo Films, 2013.

2. Richard Brody. "Michael Haneke's Sterile 'Amour'." The New Yorker, 4 January 2013. Available online: http://www.newyorker.com/culture/richard-brody/michael-hanekes-sterile-amour (accessed on 4 June 2016).

3. Roy Grundmann. "Love, Death, Truth-Amour." Senses of Cinema, December 2012. Available online: http:/ / sensesofcinema.com/2012/feature-articles/love-death-truth-amour/ (accessed on 4 June 2016).

4. Roy Grundmann, ed. A Companion to Michael Haneke. Oxford: Wiley-Blackwell, 2010.

5. Francine Prose. “A Masterpiece You Might Not Want to See." The New York Review of Books, 7 January 2013. Available online: http:/ /www.nybooks.com/daily/2013/01/07/haneke-film-not-to-see/ (accessed on 4 June 2016).

6. Dave Calhoun. “Michael Haneke Interview." Time Out London, November 2012. Available online: http://www. timeout.com/london/film/michael-haneke-interview-2 (accessed on 5 June 2016).

7. Merold Westphal. God, Guilt, and Death: An Existential Phenomenology of Religion. Bloomington: Indiana University Press, 1984.

8. Marc Crépon. The Thought of Death and the Memory of War. Translated by Michael Loriaux. Minneapolis: University of Minnesota Press, 2013.

9. Todd Dubose. "Lived Theology." In Encyclopedia of Psychology and Religion, 2nd ed. Edited by David A. Leeming. New York: Springer, 2014, vol. 2, pp. 1033-35.

10. Peter Brunette. Michael Haneke (Contemporary Film Directors). Urbana and Chicago: University of Illinois Press, 2010.

11. Michael Haneke. "Violence and the Media." In A Companion to Michael Haneke. Edited by Roy Grundmann. Oxford: Wiley-Blackwell, 2010, p. 579.

12. Ben McCann, and David Sorfa, eds. The Cinema of Michael Haneke: Europe Utopia-Director's Cuts. London: Wallflower Press, 2011.

13. Mattias Frey. "A Cinema of Disturbance: The Films of Michael Haneke in Context." Senses of Cinema, October 2003. Available online: http://sensesofcinema.com/2003/great-directors/haneke-2/ (accessed on 4 June 2016).

14. Kevin L. Stoehr. "The Anti-Nihilism of Kubrick and Haneke." Four by Three Magazine, 8 April 2016. Available online: http://www.fourbythreemagazine.com/issue/nihilism/the-antinihilism-of-kubrick-andhaneke (accessed on 4 June 2016).

15. Kevin L. Stoehr. "Haneke's Secession: Perspectivism and Anti-Nihilism in Code Unknown and Caché." In A Companion to Michael Haneke. Edited by Roy Grundmann. Oxford: Wiley-Blackwell, 2010, pp. 477-94.

16. Catherine Wheatley. Michael Haneke's Cinema: The Ethic of the Image. New York: Berghahn Books, 2009, vol. 7. 
17. Sebastian Heiduschke. "The Pleasure of Unpleasure: Ethics of Film Spectatorship. Review of Catherine Michael Haneke's Cinema: The Ethic of the Image." H-German, December 2009. Available online: http:/ / www.h-net.org/reviews/showrev.php?id=25902 (accessed on 4 June 2016).

18. Milosz Paul Rosinski. "Touching Nancy's Ethics: Death in Michael Haneke's Amour." Studies in French Cinema 15 (2015): 180-96. [CrossRef]

19. Martin Heidegger. Being and Time. Translated by John Macquarrie and Edward Robinson. Oxford: Blackwell, 1962.

20. George Pattison. Heidegger on Death. Burlington: Ashgate, 2013.

21. Dietrich Bonhoeffer. Barcelona, Berlin, New York: 1928-1931. Edited by Clifford J. Green. Minneapolis: Fortress Press, 2008, vol. 10.

22. Simon Critchley. "Being and Time Part 6: Death." The Guardian, 13 July 2009. Available online: http:/ / www. theguardian.com/commentisfree/belief/2009/jul/13/heidegger-being-time (accessed on 4 June 2016).

23. The White Ribbon. Directed by Michael Haneke. Berlin: X-Filme, 2009.

24. Amour. Directed by Michael Haneke. Paris: Les Films du Losange, 2012.

25. Ben McCann. "Acting, Performance and the Bressonian Impulse in Haneke's Films." In The Cinema of Michael Haneke: Europe Utopia. Edited by Ben McCann and David Sorfa. New York: Columbia University Press, 2011, p. 28.

26. Jacques Derrida. The Work of Mourning. Edited by Pascale-Anne Brault and Michael Naas. Chicago: University of Chicago Press, 2001.

27. Dietrich Bonhoeffer. Act and Being: Transcendental Philosophy and Ontology in Systematic Theology. Translated by Martin H. Rumcheidt. Edited by Wayne Whitson Floyd. Minneapolis: Fortress Press, 1996, vol. 2.

28. Dietrich Bonhoeffer. "The Anthropological Question in Contemporary Philosophy and Theology." In Barcelona, Berlin, New York: 1928-1931. Minneapolis: Fortress Press, 2008, vol. 10, pp. 389-408.

29. Dietrich Bonhoeffer. Letters and Papers from Prison. Translated by Isabel Best, Lisa E. Dahill, Reinhard Krauss, Nancy Lukens, Barbara Rumschiedt, Martin Rumschiedt and Douglas W. Stott. Edited by John W. De Gruchy. Minneapolis: Fortress Press, 2009, vol. 8.

30. Mark Kermode. "Mark Kermode's DVD Round-Up." The Guardian, 16 March 2013. Available online: https:/ /www.theguardian.com/film/2013/mar/17/amour-master-dvd-mark-kermode (accessed on 27 June 2016).

31. Kermodeandmayo. "Amour reviewed by Mark Kermode." YouTube, 2012. Available online: https://www. youtube.com/watch?v=iJMceF5ZXk0 (accessed on 26 June 2016).

(C) 2016 by the author; licensee MDPI, Basel, Switzerland. This article is an open access article distributed under the terms and conditions of the Creative Commons Attribution (CC-BY) license (http://creativecommons.org/licenses/by/4.0/). 